\title{
Improving EFL Reading Habits in Adolescent Students from Public High Schools in Ecuador
}

\author{
Mayra Jaramillo-Ponton, Alba Vargas-Saritama, Paola Cabrera-Solano, Leidy \\ Vivanco-Rios and Alexandra Zuniga \\ Universidad Técnica Particular de Loja \\ Loja, Ecuador
}

\begin{abstract}
This study was aimed at determining students' reading habits in English as a Foreign Language through the implementation of reading corners and workshops, and how teachers and parents motivate students to enhance reading habits. The participants were 63 English teachers, 374 parents, and 1300 students who belonged to eighth, ninth, and tenth years of high schools in the coast, sierra, and Amazon regions of Ecuador. A mixed-method approach with qualitative and quantitative methods was used to collect and analyze data for six months. The instruments applied were students, teachers, and parents' questionnaires, observation sheets, and teachers' and authorities' interviews. The results of this research showed that students' EFL reading habits were very weak before the intervention. Most of the teachers and some parents motivated students to improve their EFL reading skills through different techniques, strategies, activities, and educational resources; however, the implementation of workshops and reading corners contributed to enhancing this skill.
\end{abstract}

Keywords: reading habits; reading comprehension; English as a Foreign Language; motivation; adolescent students.

\section{Introduction}

Nowadays, methodologies for teaching and learning English as a foreign language need to be strengthened. These teaching methodologies should encourage the improvement of reading, listening, speaking, and writing skills, so that students can use the language in different ways to communicate effectively.

In this context, being reading one of the most challenging skills to learn, it has been chosen as the focus of this study. Today, it is common to find students who do not understand what they read due to the lack of skills to process information, the absence of practice, among other reasons. Hence, this is why it can be affirmed that students from most of the Ecuadorian educational 
institutions demonstrate certain deficiencies when learning English as a foreign language. This fact does not allow them to make a critical analysis of the texts, understand instructions, reflect on relevant information, and thus be able to contribute to what they read.

Ahmed (2011) believes that reading is a vehicle for learning, the development of intelligence, the acquisition of culture, and the education of the will. In the same way, learning EFL reading is extremely important because it allows immediate access to sources of information to know new cultures, focus the attention, expand vocabulary, improve spelling which enhances the ability of oral and written communication.

Some authors have investigated the importance of reading habits in EFL learning at different educational levels. For instance, Iftanti (2015) carried out a study to explore what makes EFL learners establish good reading habits in English. Similarly, McGeown, Duncan, Griffiths and Stothard (2015) investigated the extent to which adolescents' reading motivation and reading habits influence on reading development. Furthermore, Mansor (2017) pointed out the importance of the role of government and community in the development of effective reading habits. All these authors have agreed that accessibility to reading materials and resources guided by teachers and parents has a strong effect on improving students' reading attainment.

EFL teaching in Ecuadorian educational institutions usually faces some challenges, especially in public institutions. In this respect, this study aimed to provide practical solutions to teachers, students, and parents to improve and enhance students' EFL reading habits. For this purpose, students' reading habits were determined, and workshops and reading corners implemented at public high schools.

\section{Literature Review}

2.1. EFL Reading Comprehension. Comprehension is considered the purpose of reading. Albarran, Albarrán, Arenas and Moreno (2016) highlight that reading comprehension is the construction of meaning, which involves a group of phases and cognitive and metacognitive strategies. For most second language learners who know how to read in their mother tongue, reading comprehension can be developed through the use of appropriate and useful strategies (Brown, 2001). Moreover, Ness (2016) states that there is clear evidence that reading comprehension instruction is highly beneficial for students of all levels. The author remarks on the importance of explaining and modeling a single comprehension strategy or multiple strategies, as well as providing guided and independent practice with feedback until students begin to use the strategies independently.

Concerning one of the strategies that motivates students to read, Brown (2001, p. 306) states, "efficient reading consists of clearly identifying the purpose in reading something.", since it provides readers with a clear idea of the purpose of reading. A second strategy is to provide students with some explanations about 
patterns of English orthographic rules, for example, gathering words with similar features like final silent vowel and so on. Meneau, Ricketts and Deacon (2018) indicate that orthographic learning predicts word reading directly and reading comprehension indirectly via word reading. This third strategy is appropriate for intermediate or advanced levels. It relates to silent reading where readers do not need to pronounce each word, and they can perceive more than one word at a time and infer the meaning of unknown words. Among others, these authors emphasize on the comprehension of discourse markers that can enhance learners' reading efficiency. It is essential to highlight that reading comprehension can improve by teaching learners to apply cognitive strategies to face reading comprehension difficulties.

2.2. EFL reading Motivation. One of the most effective ways of learning is through reading since it allows learners access to updated knowledge, which turns into academic, personal, and professional development. Reading, in the EFL learning context, becomes an essential skill because it provides learners content and language input. In fact, when learners read, they can access not only to a wide range of information but also to get in touch with vocabulary, spelling, and grammar of the target language using diverse types of sources. According to Harmer (2007), reading is a fundamental skill in language acquisition; however, without the will to read, students are not likely to become a good reader (Cambria \& Guthrie, 2010).

Despite the importance and usefulness of reading, not all EFL learners like to read because this skill highly depends on motivation. As stated by Dornyei and Ushioda (2011), motivation deals with the impetus or action why people move to do something and the time and effort they devote to achieve it successfully. This motivation can be intrinsic or extrinsic. Extrinsic motivation refers to the purpose of learning a new language through rewards (Setiyadi, Mahpul \& Wicaksono, 2019); in this sense, teachers can enhance extrinsic motivation by offering them plenty of pedagogically selected material, according to students' needs, and by supplying them with an exciting and relaxed environment. On Intrinsic motivation is related to engagement in behavior that is inherently satisfying or enjoyable (Levesque, 2011). It comes from within students.

2.3. EFL Reading Habits. According to Mohd (2011), the ability to read is at the heart of self-education and lifelong learning. It is a vital resource for the acquisition of new knowledge, since it provides opportunities for language (L2) development in second language learners (Day \& Bamford, 1998). Based on the importance of reading, the development of good EFL reading habits is fundamental for the acquisition of all language skills.

Regarding reading habits, Shen (2006) identifies them as to how often, how much, and what students read. Similarly, Sangkaeo (1999) mentions that reading habits refer to the behavior which expresses the likeness of reading. Hence, students who learn English as a foreign language must establish a good behavior pattern about the frequency, amount of time, and type of material they read when involved in English reading practices (Iftanti, 2012). 
Therefore, learners must be encouraged to develop reading habits by teaching them strategies and how to apply them to facilitate reading comprehension in any reading context (Yazar, 2013).

2.4. EFL Reading strategies. Reading strategies are defined as the approaches, actions, and procedures used to improve reading comprehension, which serves as the basis to acquire new knowledge and to better understand the world that surrounds us. Similarly, Brantmeier (2002), cited in Marashi and Rahmati (2017), remarks that reading strategies deal with the understanding process that learners apply to comprehend what they read. For this reason, students who learn by using good reading strategies, especially in a foreign language, are more capable of understanding any reading material, which might help them to expand their minds and go beyond barriers.

Souhila (2014) argues that some of the most useful strategies that will enable EFL learners to achieve a good level of reading comprehension include techniques such as skimming, scanning, inferring, and guessing meaning. It is vital to bear in mind that when using the correct strategies, learning becomes a conscious process that can be improved and mastered through comprehensive reading.

2.4.1. Skimming and scanning. Halimatul, Sundari and Sukmaantara (2015) state that skimming refers to the ability to get an overall impression by finding general ideas or information. In contrast, scanning deals with the ability to find specific information without reading the whole text and having in mind a particular point to be found. In spite of these differences, skimming and scanning share a similarity, both help readers to extract information rapidly (Berregui \& Boulaachab, 2017).

2.4.2. Inferring. It refers to the understanding of a message that has been concluded implicitly instead of being directly stated. This strategy plays an essential role in reading skills since it challenges learners to critically think when reading any material. In this regard, Bailey (2017) states that the inferencing strategy permits readers to combine previous personal knowledge with what they read to understand the text.

2.4.3. Guessing meaning from context. In cases in which readers do not understand the meaning of words, they might use the context to clarify what the text means. As explained by Tuğrul (2012), one of the most effective ways of vocabulary learning is guessing the meanings of words from context.

Additionally, Chen and Chen (2015, p.156) state that "good reading strategies will help learners not only to understand general information in the reading text high-speed rates but also to remember new lexical items from the text." Hence, they will also improve their vocabulary and their writing since they will remember how it should be done correctly in every context.

All of these reading strategies facilitate learners to understand faster the general ideas, and also to recognize new lexical items within the text (Chen \& Chen, 
2015). They also help readers to decode information, thus developing comprehensive reading skills and becoming purposeful readers.

\subsection{Previous Studies.}

Various studies have been conducted on EFL reading habits around the world. Iftanti (2015) carried out a multi-case study to explore what makes EFL learners establish good reading habits in English. To perform this study, 5 EFL college students who already established good English reading habits were chosen. The data were collected by doing in-depth interviews and home observations to describe and identify factors that are only under the knowledge and experience of the subjects. The results proved that factors like individual, social, cultural, and technological construct set up good reading habits in EFL learners. Moreover, people develop good reading habits if they are in an environment where parents are used to reading in their native language and have access to digitized reading material.

Gamboa-Gozález (2017) conducted a study to describe and analyze reading comprehension processes in an EFL setting through the implementation of strategies based on an Interactive Model of reading at a private school in Bogotá. The participants were 20 students (10 boys and 10 girls) in 6 grade. This research work used different instruments to collect data. First, field notes were written after each reading session (16 sessions). A pre and post questionnaire was applied. Students' journals were used to collect their perception of the reading plan before, while, and after the implementation. Finally, the activities as workshops (artifacts) were used to identify their reading process in a foreign language. The findings revealed that the events based on the Interactive Model of reading helped students comprehend the stories by creating meaning. Moreover, it was found out that students were able to activate their schemata using their previous knowledge and experiences, make predictions, confirm their guesses, and compensate weaknesses.

A study conducted by Mansor (2017) highlights the high importance of the role of government and community in the development of effective reading habits. The purpose of this research was to explore the perceptions of EFL students' reading habits and the constraints they face when learning to read in a foreign language. The findings of this study show that one of the main problems that affect students' perceptions of the development of good reading habits is their misconception that reading must be mainly for academic purposes. It was also found that teachers do not encourage their students to read more materials in English to increase their reading level. The study concludes that for society to have good readers, it is necessary the commitment of government, parents, and teachers.

Mohd (2011) conducted a study aimed to identify the reading habits and preferences of EFL postgraduates enrolled in an English Proficiency program. The participants were 52 (19 females and 33 males) students whose ages ranged between 20 - 45 years old. Data were collected through a questionnaire that was analyzed quantitatively. The results revealed that the materials students 
preferred were internet-based materials, emails, textbooks, dictionaries, novels, storybooks, among others. Furthermore, pleasure and study habits were cited as the most important reasons for reading; however, the participants preferred to read the material in their mother tongue because of their lack of fluency and vocabulary in the target language.

In the same way, McGeown, Duncan, Griffiths and Stothard (2015) explored the extent to which adolescents' reading motivation and reading habits influence reading development. A representative sample of 1,230 high school students took part in this study. The data was collected through a reading assessment test, a questionnaire, and reading comprehension passages. Findings confirmed that aspects like word reading, comprehension, summarization, and text reading speed showed to have a considerable impact on adolescents' reading motivation and habits. Additionally, it was noticed that dimensions of motivation (expectancy and value), reading habits and material like fiction books and digital texts have a substantial effect on improving reading attainment.

Based on the aspects analyzed in the previous studies, the research questions to be addressed in this study deal with:

1) What are high school students' reading habits in English as a Foreign Language?

2) Does the implementation of reading corners and workshops in EFL classrooms help students to improve their reading habits?

3) How do teachers and parents' guidance motivate students to enhance EFL reading habits?

\section{Method}

3.1. Setting and participants. This study was conducted in public high schools located in the coast, highlands and Amazon regions of Ecuador. The participants were 1300 EFL students from eighth, ninth, and tenth years of high school, whose ages ranged between 11 - 14 years old. They belonged to an A1 proficiency level according to the Common European Framework of Reference for Languages (CEFR). Moreover, 63 English teachers and 374 parents participated in this research.

A total of 90 pre-service and five university teachers participated as researchers and were in charge of administering surveys, giving reading workshops, and implementing reading corners in the participant institutions.

\subsection{Instruments}

1) A students' questionnaire was administered to determine reading habits in terms of preferences, frequency, motivation, time spent, among other aspects.

2) Teachers' and parents' questionnaires were applied to determine how guidance motivates students to read English materials and strengthen reading habits. 
3) The authorities of the participating institutions were interviewed to obtain first-hand information regarding the promotion of reading habits in the English area.

4) Observation sheets were used to determine the effectiveness of the reading strategies used by teachers to enhance reading comprehension and habits.

5) Teachers and authorities' interviews were held to know the actions that the institutions have promoted to enhance EFL reading habits.

\section{Procedure}

This study was conducted during 6 months under a mixed-method approach in which qualitative and quantitative methods were used to collect and analyze data. According to Ary, Jacobs, Irvine and Walker (2018), the integration of these two methods in different ways helps to the understanding of the research problem or phenomenon.

4.1. Stage one. At the beginning of the study, questionnaires were applied to high school students, teachers, and parents to diagnose their English reading habits and how motivated they were to enhance this skill.

4.2. Stage two. With the information provided, first, reading workshops were planned by pre-service teachers to teach students some reading strategies focused on the fundamental aspects that should be considered to understand written materials in English as a foreign language. The topics used in each workshop were related to subjects that the students were studying in high school such as, Science, Math, Social Science, among others. These workshops were organized and performed by EFL pre-service teachers who were in charge of selecting pertinent materials according to the students' level and age. While conducting the workshops, observations were carried out by university teachers to determine the effectiveness of the reading strategies used by pre-service teachers to enhance reading comprehension and habits in the classroom. Furthermore, teachers and parents received some workshops to be aware of the importance of promoting reading habits in young learners.

4.3. Stage three. After teachers and students' training on the most common reading strategies, students with the guidance and help of pre-service teachers were able to identify and design appropriate materials to create reading corners in all the participating institutions around the country. Among the activities, students created reading materials like authentic stories by using their creativity, and educational material, such as flashcards, posters, word-cards, worksheets, among others.

4.4. Stage four. In the final step, students created reading corners by using their creativity and motivation to provide a comfortable place to enhance reading. According to $\mathrm{Ni}^{\prime}$ mah (2018), a reading corner is a strategy aimed at improving students' reading skills through the use of classroom corners as places to store material available for students at any moment. A welcoming, warm, and appealing physical environment was carefully selected and authorized to set the 
English reading corners, which were adapted to inspire students to apply the reading strategies learned in the workshops. To complement these corners, students planned a donation campaign through traditional and digital media to provide a consistent stock of English reading material.

\section{Results and Discussion}

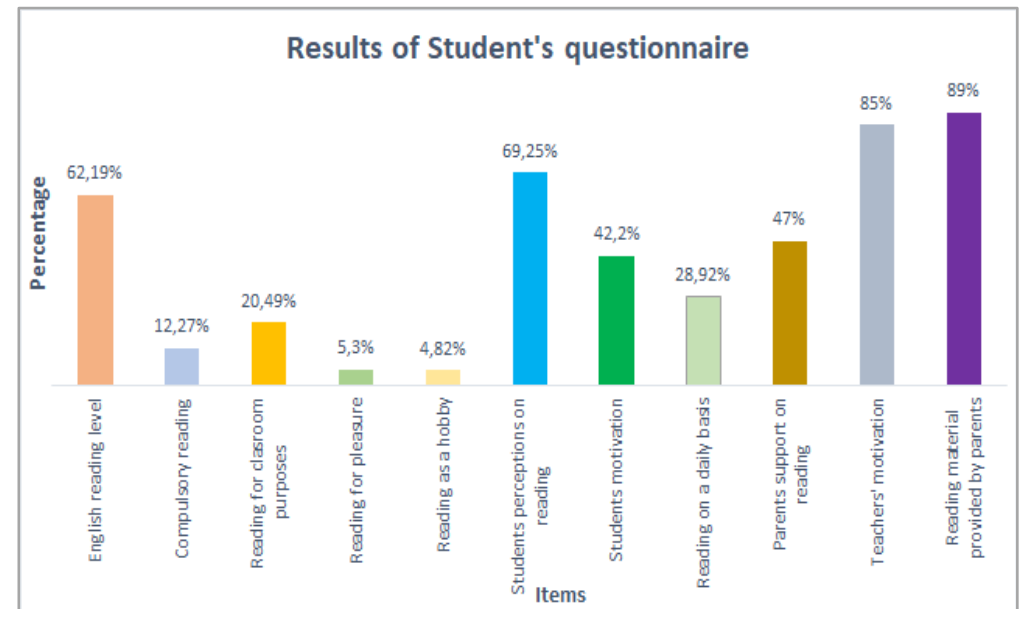

Figure 1: Results of students' questionnaire

In regards to students' reading habits, Figure 1 shows that the majority of participants (62.19\%) could not read in English, while $37.81 \%$ stated they could do it. Even though the majority of the students could not read in English, 20,49\% said they just read for classwork purposes, and $12,27 \%$ read because they had to. Reading for pleasure and reading as a hobby, considered as intrinsic motivation, were the least reasons why students practiced this skill, with only $5,3 \%$ and $4,82 \%$, respectively. All these points of view were confirmed by parents who corroborated that students' habits were weak because they just read when they had to complete assignments. In this respect, Iftanti (2015) states that reading, as a long term habit, is significant for EFL students because they can achieve academic success in the target language.

In spite of having a low reading level, most of the students $(69.25 \%)$ and the majority of parents stated that this skill is necessary to understand a variety of topics and improve academic performance. For this reason, $42.2 \%$ of the students felt motivated to read in English; however, only $28.92 \%$ of them read daily. Concerning students' opinions regarding the motivation they receive by their parents to read in English, $47 \%$ affirmed that their parents encourage them to read in the target language. In addition, $85 \%$ of the students declare that their teachers highly motivate them to read using different activities. In respect to parents' opinions, 89\% manifested that they buy stories and movies in English to motivate their children to read in this foreign language, and just a few of them claimed that they allow their children to attend language academies or English courses. Only a low percentage of parents, $11 \%$, manifested that they do not motivate their children to enhance this skill. 
On the other hand, teachers claimed that parents do not play an active role in inspiring students to read in English; for this reason, teachers highlighted that they try to encourage them to read by using different techniques and strategies both, in class and extra class, and by providing various types of texts. In this regard, Bano, Jabeen and Quitoshi (2018) state that parents play an essential role in learners' reading improvement, who, apart from providing their children with enough material to practice this skill, also have to motivate them to develop this habit since their childhood. Similarly, these authors argue that both parents and teachers must help students understand the importance of the reading material they use and the purpose of reading it.

Based on the diagnostic results, an intervention that consisted of 378 reading workshops was organized through the strategies described in Table 1. These workshops were addressed to English teachers and students, who were trained on topics related to EFL reading strategies, reading texts of specific areas, and tips for reading motivation. The workshops were designed using an active learning approach in which the participants practiced the reading strategies concerning each topic proposed.

Table 1. EFL reading workshops

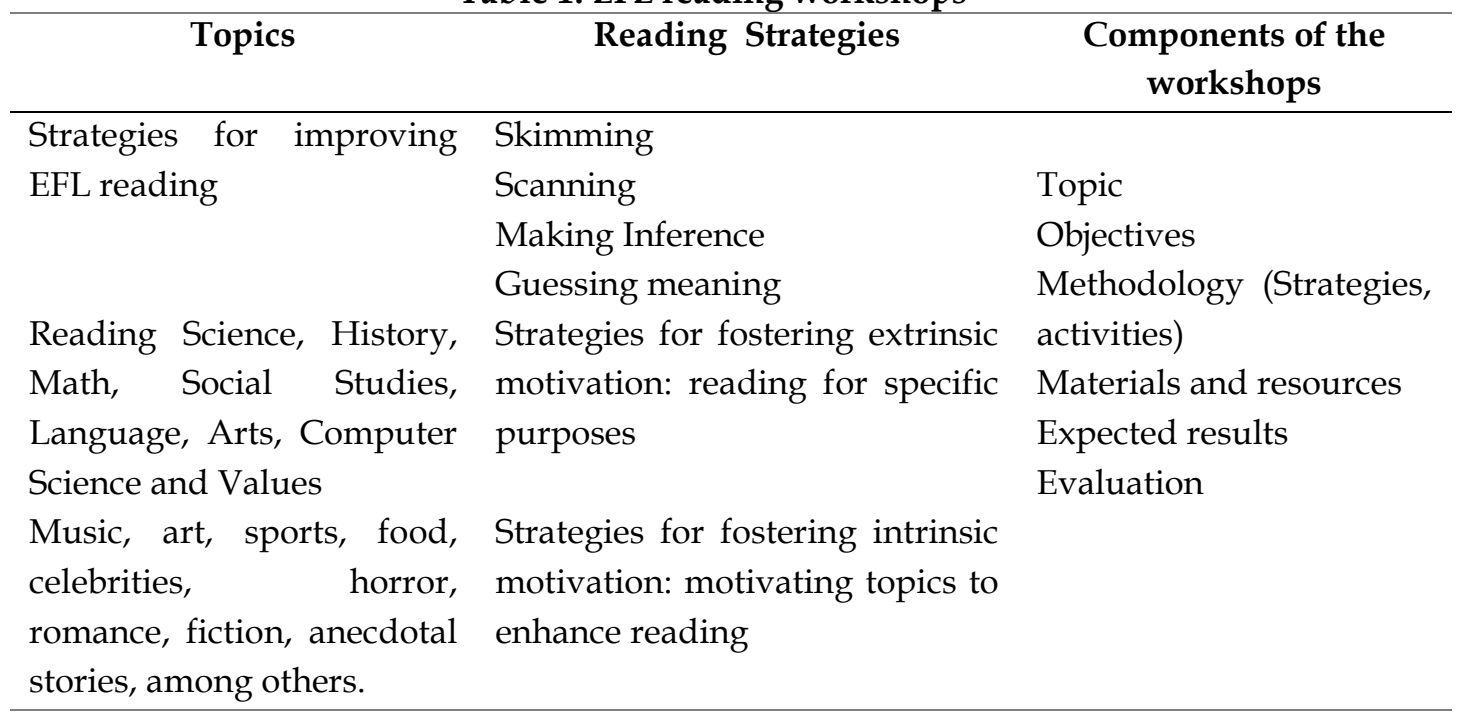

To identify the relevance of creating EFL reading corners as an institutional strategy to motivate students to develop reading habits in the target language, it was also necessary to gather information from authorities and teachers. Some of the main reasons that they perceived as fundamental were related to the aspects shown in Table 2:

Table 2. Reasons to implement reading corners in the educational institutions

\begin{tabular}{l} 
Institutional needs \\
\hline Low proficiency level \\
Time devoted to teaching English \\
Lack of libraries \\
Lack of reading material \\
Lack of teachers' training \\
\hline
\end{tabular}


During the implementation of workshops and reading corners, students were observed to be more motivated to work in the reading activities planned by their teachers. Similarly, students found it easy to understand the contents by applying reading strategies such as skimming, scanning, making inferences, and guessing meaning from context. It is essential to mention that, according to the authorities, these workshops were beneficial for students and teachers to raise awareness of the importance of reading in a foreign language. Additionally, after implementing the reading corners through this intervention, teachers stated that having these resources allowed them to plan more exciting reading activities that can catch students' attention and facilitate the EFL learning process. In the same fashion, students evidenced a high willingness to read about topics of their interest in appropriate spaces created for that purpose. It is corroborated by Mohseni and Reza (2017), who consider that to make the reading activity enjoyable and increase students' motivation, teachers should provide suitable physical spaces.

Even, Smith and Dechant (1961) suggest encouraging students to practice and develop the reading skills through having a motivational reading program that can foster a physical environment and social interactions between these students. In the same way, Guthrie, Hoa, Wigfield, Tonks, Humenick and Littles (2007) underline that when the physical space for reading purposes is transformed, intrinsic motivation can be promoted; especially, specific aspects such as the involvement or social interaction.

\section{Conclusion}

Students' EFL reading habits are very weak despite believing that reading is a vital aspect of the language. Even though students perceive reading as an essential skill, most of them do not master strategies to help them understand the main ideas and relevant details from context. For this reason, they read just because they need to accomplish academic tasks, but not because they want to improve this skill.

Most teachers and some parents motivate students to improve their EFL reading skills. Teachers encourage learners to practice reading by applying different techniques, strategies, activities, and educational resources through in and extraclass assignments. Similarly, parents try to motivate their children to practice the skill mentioned above by providing them with some reading material and enrolling them in additional EFL courses.

Developing EFL reading workshops and implementing reading corners did improve learners' reading skills and enhance their intrinsic motivation. Through these workshops, students developed effective reading strategies and learned to use reading material properly and more frequently. Also, teachers improved their teaching strategies to design more engaging reading activities and facilitate the EFL learning process. In addition, reading corners provided teachers and students with adequate physical space to keep them motivated to practice their EFL reading skills. 


\section{References}

Ahmed, M. (2011). Importancia de la lectura en infantil y primaria [Importance of reading in children and primary school]. Revista digital innovación y experiencias educativas, 38 .

Albarran, J., Albarrán, S., Arenas, L., \& Moreno, D. (2016). El proceso de comprensión lectora en lengua inglesa de los estudiantes de ingeniería: La webquest como herramienta para aprender a leer [The process of reading comprehension in English language of engineering students: The webquest as a tool to learn to read]. ARJÉ. Revista de Postgrado FaCE-UC, 10(19).

Ary, D., Jacobs, L. C., Irvine, C. K. S., \& Walker, D. (2018). Introduction to research in education. Cengage Learning.

Bailey, E. (2017, July 9). Making inferences to improve reading comprehension. Retrieved from https://www.thoughtco.com/making-inferences-3111201

Bano, J., Jabeen, Z., \& Quitoshi, S. (2018). Perceptions of Teachers about the Role of Parents in Developing Reading Habits of Children to Improve their Academic Performance in Schools. Journal of Education and Educational Development, 5(1) 4259. Retrieved from https:// files.eric.ed.gov/fulltext/EJ1180618.pdf

Berregui, O., \& Boulaachab, W. (2017). The Role of Skimming and Scanning in Developing Reading Abilities in ESP Class (Master's thesis). Kasdi Merbah University, Ouargla, Algeria.

Brown, H. D. (2001). Teaching by Principles: An Interactive Approach to Language Pedagogy. (2nd. Ed). White Plains, NY: Pearson Education.

Cambria, J., \& Guthrie, J. T. (2010). Motivating and engaging students in reading. New England Reading Association Journal, 46(1), 16-29.

Chen, K. \& Chen, S. (2015). The Use of EFL Reading Strategies among High School Students in Taiwan. The Reading Matrix: An International Online Journal, 15(2) 156166. Retrieved from www.readingmatrix.com/files/13-m0137054.pdf

Day, R., \& Bamford, J. (1998). Extensive reading in the second language classroom. Cambridge: Cambridge University Press.

Dornyei, Z., \& Ushioda, E. (2011). Teaching and Researching Motivation. (2nd ed.). Longman: England.

Gamboa-González, Á. M. (2017). Reading Comprehension in an English as a Foreign Language Setting: Teaching Strategies for Sixth Graders Based on the Interactive $\begin{array}{llll}\text { Model of } & \text { Reading. }\end{array}$ https://doi.org/10.17227/01234870.45folios159.175

Guthrie, J. T., Hoa, A. L. W., Wigfield, A., Tonks, S. M., Humenick, N. M., \& Littles, E. (2007). Reading motivation and reading comprehension growth in the later elementary years. Contemp. Educ. Psychol. 32, 282-313. https:// doi.org/10.1016/j.cedpsych.2006.05.004

Halimatul, L., Sundari S., \& Sukmaantara P. (2015). The Effect of Using Skimming and Scanning Techniques on the Eighth Grade Students' Reading Comprehension Achievement of Recount Texts at SMPN 1 Silo Jember. Artikel Ilmiah Mahasiswa, $1,1-4$.

Harmer, J. (2007). The practice of English language teaching. Harlow: Pearson Longman.

Iftanti, E. (2012). A survey of the English reading habits of EFL students in Indonesia. Teflin Journal, 23(2), 149-164.

Iftanti, E. (2015). What makes EFL students establish good reading habits in English. International Journal of Education and Research, 3(5), 365-374.

Levesque, R. J. R. (2011) Intrinsic and Extrinsic Motivation. In: Levesque R.J.R. (eds) Encyclopedia of Adolescence. Springer, New York, NY

Mansor, N. (2017). Exploring perceptions on ESL students' reading habits. Journal of Business and Social Development, 5(2), 19-24 
Marashi, H., \& Rahmati, P. (2017). The Effect of Teaching Reading Strategies on EFL Learner's Reading. International Journal of Research in English Education, 2(2). 4352. https://doi.org/10.18869/acadpub.ijree.2.2.43

McGeown, S. P., Duncan, L. G., Griffiths, Y. M., \& Stothard, S. E. (2015). Exploring the relationship between adolescent's reading skills, reading motivation and reading habits. Reading and Writing, 28(4), 545-569. https://doi.org/10.1007/s11145014-9537-9

Meneau, C., Ricketts, J., \& Deacon, S. H. (2018). The Role of Orthographic and Semantic Learning in Word Reading and Reading Comprehension. Scientific Studies of Reading, 22(5), 384-400. https:// doi.org/10.1080/10888438.2018.1464575

Mohd, N. (2011). Reading habits and preferences of EFL post graduates: A case study. Indonesian Journal of Applied Linguistics, 1(1), 1-9.

Mohseni, N., \& Reza, M., (2017). The effect of learners' motivation on their reading comprehension skill: A literature review. International journal of research in English education, 2(3), 10-21. https://doi.org/10.18869/acadpub.ijree.2.3.10

Ness, M. (2016). Reading Comprehension Strategies in Secondary Content Area Classrooms: Teacher Use of and Attitudes Towards Reading Comprehension Instruction. Reading Horizons: A Journal of Literacy and Language Arts, 49(2). Retrieved from https://scholarworks.wmich.edu/reading_horizons/vol49/iss2/5

Ni'mah, K. (2018). The implementation of reading corner and teacher modeling in Indonesian learning through psycholinguistic approach. MUDARRISA: Jurnal Kajian Pendidikan Islam, 10(1), 47-72. https://doi.org/10.18326/mdr.v10i1.47-72

Sangkaeo, S. (1999). Reading habit promotion in Asian libraries. 65th IFLA Council and General Council and General Conference, Bangkok, Thailand, August 20- 28.

Setiyadi, B., Mahpul, \& Wicaksono, A. (2019). "Exploring motivational orientations of English as foreign language (EFL) learners: A case study in Indonesia". South African Journal of Education, 39(1), 1-12. https:// doi.org/10.15700/saje.v39n1a1500

Shen. L. (2006). Computer Technology and College Students' Reading Habits. Chia-nan annual bulletin, 32, pp. 559-572

Smith, H. P., \& Dechant, E. V. (1961). Psychology in teaching reading. Englewood Cliffs, NJ: Prentice-Hall.

Souhila, R. (2014). The Use of Reading Strategies in Improving Reading Comprehension (Master's thesis). University Kasdi Merbah Ouargla, Ouargla, Algeria.

Tuğrul, Ç. (2012). Guessing the meanings of words from context: Why and how. International Journal of Applied Linguistics and English Literature, 1(6), 177-181.

Yazar, U. (2013). Teaching reading to EFL students to make them better readers. Journal of Studies in Education, 3(3), 35-48. https://doi.org/10.5296/jse.v3i3.3895 